\author{
Andrzej DUDEK \\ Jagiellonian University in Kraków \\ e-mail: andrzej.dudek@uj.edu.pl
}

\title{
ON SOME ASPECTS OF WORD, IMAGE \\ AND HUMAN VALUES AS REFLECTED \\ BY RUSSIAN ORTHODOX ICONS AND WESTERN RELIGIOUS PAINTINGS
}

ABSTRACT The main focus of interest in the paper is the attitude of Western and Eastern stems of Christianity towards religious painting with reference to the problem of equality of word and image as far as the Church teaching is concerned. The roots and basic notions of Christian anthropology as well as positions revealed by both Churches during the discussions in $7-8^{\text {th }}$ centuries are regarded as foundations for noticeable differences in interpretations of meanings, means, artistic principles, reality representations, ways of passing on the truth on man in Orthodox icons and Western religious paintings either. Taking in to account the relationship between object and its representation the paper develops the idea of metonymical principle being crucial for Western religious paintings and symbolic connection between signans belonging to the earthly reality and signatum pointing out to transcendent realm in Orthodox icon painting.

Keywords: word, image, Russian Orthodox icon, western religious painting, axiology 
$\mathrm{T}$ he Eastern and Western stems of Christianity coming from the single source of the Revelation and referring to the same Holy Scriptures and the same tradition of the first centuries of Christianity have developed their own visions of man resulting in different representations of anthropological views in the visual arts and even in literature.

Dogmatic discussions that focused on the problem of the origin of the Holy Spirit the third person of God (cf. HRYNIEwICZ 1972: 219) resulted in a schism that was formally announced in 1054. The dogmatic split brought about consecutive changes in the teaching developed by the Eastern and Western Churches. Regarded as the inspiring powers of Western and Eastern cultures, both Churches encouraged the development of different value orientations and patterns of culture, concepts of the person, possible ways of Redemption, views on man's relationships with his community and the acceptable shapes of his freedom as well.

The basic idea for Christian anthropology is expressed in the biblical statement from Genesis about the creation of man in the image and likeness of God [Gen 1:27]. According to Christian theology, the image of God is given to everybody and it is present even in the soul of the sinner (cf. ŠPIDLÍk 2005: 92), whereas the likeness is regarded as a task for man invited to become alike to God (cf. MEYENDORFF 1984: 184). One of the most important aspects of Christian anthropology is the idea of the person (cf. Lossky 1985: 137). For the first time the notion of the person was developed in the Trinitarian dogma, pronounced by the First Council of Nicaea in 325 (cf. LECLERCQ 1911), passing on the idea of God appearing in 3 persons (the Father, the Son, and the Holy Spirit; these Three Persons being truly distinct one from another, but appearing in the unity of the Godhead) (MEYENDORFF 1984: 236). Simply from this dogma, the notion of a person was transferred to Christian teaching on the essence of man, stating that the person in the absolute sense is God itself, whereas man can be perceived as a person due to the fact that he was created in the image and likeness of God (cf. LossKy 1985: 106-107; HRYNIEWICZ 1972: 222).

The idea of the Redemption and deification of man is another context for Christian anthropology. Orthodox thinkers used to emphasize the opinion expressed for the first time by St Irenaeus of Lyon (Adversus haereses) in the $2^{\text {nd }}$ century: "God made Himself man, that man might become God." (ST IrenAeus of Lyon: 97) That notion was repeated several times afterwards in the writings of St. Gregory of Naziansus, St. Athanasius, St. Gregory of Nyssa (cf. Lossky 1985: 97). According to the belief, the true vocation of man is the deification of his life, which means - approaching the state of a likeness of God (cf. EvDokimov 1986: 121). Eastern theologians used to point out that the path to deification leads not as much towards imitating God but rather could be described in terms of participation in divine energy and light and the inner connection between God and man (cf. Cognar 1968: 858).

Taking into account the above mentioned assumptions, Orthodox anthropology draws a conclusion by pointing to two fundamental aspects of man:

1) his true nature has been established by the image of God imprinted in his soul; 
2) his empirical form is regarded as a sort of elusive, ephemeral, changeable outer layer of person, influenced by time.

Having discerned the ambiguous aspect of ontology, Orthodox thought used to stress that man can be described in two forms of existence: a real and true one - belonging to the realm of being and unreal, and a fleeting one - specific for the realm of becoming, manifested by changing psychological appearances, resembling masks being put on frequently one after another in order to conceal the true face. ${ }^{1}$

According to Christian theology, Beauty is an ontological attribute of being (cf. JAZYKOWA 1998: 10): everything that really exists is beautiful, because any created being bears in its form information pointing out to the Creator (cf. GILson 1953: 291292). These signs are a sort of vestigia Trinitatis reflecting God's power ${ }^{2}$. Such being the case, vestigia are signs of the Creating Word - Logos ("The Word was with God and the Word was God" [John 1:1]). Created beings regarded as signs resemble symbols through their two constitutive aspects: signans and signatum ${ }^{3}$. Signans in that case stands for the visible part of the sign, the material vehicle of meaning, whereas signatum in belonging to another reality constitutes the idea of the object represented. Signatum constitutes the more valuable, ontological reality of being, whereas signans belongs to the elusive reality of becoming.

The $7^{\text {th }}$ century abounding in keen discussions between iconoclasts and iconodules appeared to be a very important time for Eastern Christianity in as far as principles of Christian aesthetics are concerned. The heated debate on the admissibility of a cult of artificial images that was mainly to involve Eastern theologians was to culminate in the acquiring and deep-rooted reverence for the canons within Eastern Church painting. At the same time, the Western branch of Christianity generally did not interfere with Eastern theological and aesthetic argument having accepted the interpretation issued by Pope Gregory the Great who, in a letter written in 600 to Bishop Serenius, explained the appropriateness and the usefulness of religious paintings being exposed in churches (cf. БезАн Сон 1999: 164). The decisions undertaken by the Second Council of Nicaea in 787 settled the Iconoclastic Controversy by stressing the symbolic character of icons enabling icon worship (cf. ŁUKASzuK 1998: 43). In the decision of the

\footnotetext{
The Platonic idea of the opposition between being and becoming was developed in the story about the ring of Giges included in Republic, Book II, 360b-d. In the history of Russian religious thought that notion has become a foundation of the anthropological concept of opposition between the true and false existence of man, developed by Vyacheslav Ivanov (1866-1949) in his several works (Fio, ergo поп sит, Человек, О кризисе гуманизма, Кризис индивудуализма, Аицо, Пролегомень о демонах. Sее: АУАЕК 2010: 53-64.

2 In the treatise De Trinitate St Augustine raised the conviction that all created things teach us something about the Creator. On Augustine's theory of natural and intentional signs see: CHydenius 1960: 5-12.

3 Roman Jakobson referring to C. S. Peirce's classification of signs (icons, indexes, symbols) presented in 1867 in the paper On A New List of Categories explains: "Stoic doctrine viewed the essence of signs, and especially of verbal signs, in their necessarily twofold structure, namely, indissoluble unity of an immediately perceptible signans and an inferable, apprehensible signatum, according to the ancient Latin translation of the corresponding Greek terms." See: JAKOBSON 1971: 699.
} 
Council Fathers, word and image were regarded as equal means for the Church teaching of transmission. That decision was to have some important anthropological connotations. One of them was the acknowledgement of the equality of the two human senses: sight and hearing. Both were regarded as appropriate to perceive God's Word (cf. БЕзАНСОН 1999: 137).

The Caroline Books (Libri Carolini) written in 790-792 exposed the Emperor Charlemagne's critique of the General Council held at Nicaea in 787 (cf. SHAHAN 1908). The Emperor supported the opinion of Pope Gregory the Great about religious paintings and stressed that the Western Church was not involved in the Iconoclastic Controversy. ${ }^{4}$ In the opinion expressed by the Pope and Emperor Charlemagne, there is neither any reason to destroy religious artificial images nor, on the other hand, -such paintings should be worshipped (cf. БезАнСОн 1999: 137). Religious paintings, however, can be useful in transmitting Church teachings to the illiterate in the form of Biblia Pauperum. According to Libri Carolini, such images may perform three functions: a) to act as a caution for common people, b) to commemorate important events and c) to serve as temple wall decoration (cf. WolickA-Wolszleger 2010: 165). The Eastern Church being seriously engaged in discussions on the appropriateness and principles of preparation and the liturgical sense of religious paintings has established the foundations for the theology of the icon - one of the most developed branches of Orthodox teaching, whereas the Western Church has not concentrated to such an extent on the meaning of visual representations (cf. DĄB-KALINOWSKA 1993: 102).

The different positions that were revealed during the argument between the Western and Eastern Churches seriously influenced ideas of artistic freedom, aesthetic styles and views on man included in the religious art developed within both cultural circles.

The word "icon" is derived from the Greek $\varepsilon ı \omega \omega \nu$ ('eikon') meaning "image." Taking that notion into account, according to Eastern theology man created "in the image and likeness of God" can be perceived as the icon of God (cf. BUŁGAKOW 2002: 50-51)..$^{5}$

An icon, in comparison with a portrait, reveals a tendency to avoid mimetic, detailed representation. An icon is not a realistic picture as far as the faithfulness and verisimilitude of reflection are concerned (cf. EvDokimov 1999: 186). A mimetic attitude towards changing reality is regarded as inappropriate or even a dangerous technique for representation because concentration on detailed reflection draws our attention away from the ontological truth. As an example of the Orthodox conviction in the inappropriateness of mimetic, realistic techniques in representing divine reality we may refer to a passage from the novel The Idiot by F. Dostoevskii. In the fragment describing the reaction of Prince Myshkin looking in Rogozhin's house at a copy of the well known

4 Jean Calvin's (1509-1564) critical views on religious paintings as elements of temple decoration are regarded by some scholars as cases of a new iconoclasm. Cf. БЕзАнСОн 1999: 201-209. The Orthodox theologian Paul Evdokimov has stated that Protestant believers do not regard art as a form of a sermon because "art does not pass on any real meaning." Cf. Evdokimov 1986: 282-283.

5 The author refers to man as a "a pan-icon of the world" also (cf. BuŁGAKow 2002: 40). 
painting The Body of the Dead Christ in the Tomb by Hans Holbein the Younger, ${ }^{6}$ Dostoevskii relates as follows:

"That picture! That picture!" cried Myshkin, ${ }^{7}$ struck by a sudden idea. "Why, a man's faith might be ruined by looking at that picture!"

This was the presentment of a poor mangled body which had evidently suffered unbearable anguish even before its crucifixion, full of wounds and bruises, marks of the violence of soldiers and people, and of the bitterness of the moment when He had fallen with the cross - all this combined with the anguish of the actual crucifixion. [...]

It is strange to look on this dreadful picture of the mangled corpse of the Saviour, and to put this question to oneself: 'Supposing that the disciples, the future apostles, the women who had followed Him and stood by the cross, all of whom believed in and worshipped Him - supposing that they saw this tortured body, this face so mangled and bleeding and bruised (and they must have so seen it) - how could they have gazed upon the dreadful sight and yet have believed that He would rise again?' (Transl. by Eva Martin).

The above mentioned picture drew the writer's attention during his journey to Switzerland in 1867 . The naturalistically presented dead body of Christ reveals the first signs of decay:

Holbein's painting equalized the human and the divine [...], his Christ is subject to the laws of physics. The two meet chiasmically in his art. When Dostoevsky encountered Holbein, he was seized by what we would call gnostic doubt: The painting, for a moment, disclosed the Resurrection as a mere hallucination and Christ as a man who really died, who once lay putrefying in a sarcophagus (MORTAL IMMORTAL).

The endangered faith of a believer looking at Holbein's picture representing the dead flesh of the Saviour becomes the source of a metaphysical feeling of horror vacui in the ekphrasis made by Prince Myshkin. The optimistic and hopeful Gospel message: "Word became flesh" [John 1:26] is confronted with a representation restricted to the earthly, profane aspects of the Incarnation without any signs of hope for an eternal life: "Holbein's painting draws the miracle of the resurrection into an unbearable, and yet all too human, encounter with the physicality of Christ's broken body." (GATRALL 2001:219.)

Such a topic can hardly appear in Orthodox iconography. In paschal icons Christ is presented either on the Cross or during the descendents to Hell. Orthodox theology does not stop at the moment of Christ's death, contemplating His overcoming of the death instead. In Orthodox icons Christ is always presented as the Lord of his life and death (cf. Evdokimov 1999: 259-260).

Der Leichnam Christi im Grabe (1521-1522), Öl auf Lindenholz, Kunstmuseum Basel.

In this quotation I have changed the spelling of the hero's name. In the translation by Eva Martin the name appears as "Muishkin." Myshkin seems to be more adequate transliteration of original Russian: Мышкин. 
Western believers and Western art do not omit the moment of the Saviour's death. Worship, songs, prayers and series of pictures are full of empathy with the suffering God, caused by images of Saviour's bleeding wounds.

The form of an icon is much simpler in comparison to the form of a portrait and any other genres of Western religious painting as well (cf. EvDokimov 1996: 128). It is believed that a portrait cannot reveal the essence of man because such a painting shows only the outer, vague and momentary layer of each person. A portrait is constructed according to the principle of pars pro toto - the part standing for the whole. The painter makes a selection of characteristic features in order to compose an individual, unique representation of the person being painted (cf. BuŁGAKOw 2002: 42, 59-61). The principle of metonymy - the tendency to keep a close, adjoin, mimetic connection between an object and its representation is characteristic for the art of the portrait, whereas an icon is organized by means of symbol - the device being part of one reality and pointing out to another one (cf. EvDokimov 1996: 118). In the realm of symbolic representation the image becomes a sign. Signans in that case stands for a material, graphic set of shapes, light and colours. Signatum constitutes the idea of the represented object belonging to another reality (cf. GADAMER 1991: 100). ${ }^{8}$

The ascetic simplicity of the means accepted by the Orthodox canons of icon preparation as well as noticeable deformations in body shapes, space, architecture, the things being presented are characteristic attempts undertaken in order to stress the symbolical meaning of the depicted world which under no circumstances can be judged in terms of a mimetic representation of sacred reality. According to canons, an icon should neither imitate nature nor make any views of illusion (cf. BUŁGAKOw 2002: 67). Such being the case, an icon makes a predominance of the semantic way of transmitting the meaning over the geometrical one, the latter prevailing in Western paintings (UsPIENSKI, 1975: 332).

In the case of an icon individual features are consciously, however not totally, reduced to reveal the spiritual image of a person. We may say that an icon is a sort of portrayal of the image of God imprinted in the soul of a person represented (UsPIENSKI, 1975: 54-56; see also: PAPROCKI 2011: 46). Because of that the icon is called a "window to the higher reality," conveying meaning from the space-time dimension to a transfigured eternity (JAZYKOWA 1998: 22).

The above mentioned differences between an icon and a portrait lead one to a specific definition of the preparation techniques adopted by icon masters. An icon, due to the acquired semantic mechanism of connection between signans and signatum, resembles a word. Therefore, in the circle of Orthodox theologians it is said that icons are not painted, but they are written. ${ }^{9}$ According to the theology of Eastern Church

Gadamer has stressed that "an inseparable connection between visible image and invisible meaning" is the characteristic feature of a symbol.

9 The contemporary Ukrainian iconographer Valentin Streltsov explains on his website: "The most

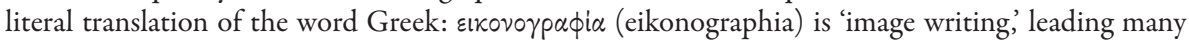
English-speaking Orthodox Christians to insist that icons are not 'painted' but rather 'written.' From there, further explanations are given that icons are to be understood in a manner similar to 
an icon is a sort of code enabling one to express the Gospel by means of colours (cf. АрХИМАНАРИт РАФАЙ).

Reduced details, simplified ways of presentation and repeated compositions are canon based principles (cf. BuŁGAKOw 2002: 64-65). A master of each icon is supposed to refer to the so-called podlinnik - a set of written instructions (sometimes accompanied by drawn patterns of composition) accepted by the Church. ${ }^{10}$ According to Eastern tradition, the true author of each icon is the Church itself whereas the master appears to be only a humble tool used by the community of believers in order to acquire the image necessary for cultic purposes. ${ }^{11}$ Consequently, a master was not supposed to sign his icons. There are clearly shaped expectations towards icon masters as far as their attitude to life is concerned. An icon master, while not being formally a monk, was subjected to more restricted behavioural practices than a real monk himself (cf. EvDOKIMOV 1999: 181-182).

In Western circumstances such restrictions have not appeared. The Church has usually not interfered with the private life of a painter. A master is not anonymous, he can sign his works. Western paintings were created in a close connection with real everyday life being a source for the individual inspiration of a painter. The task of an artist is to disclose the harmony and beauty existing in the real world but which is covered with unnecessary veils. A western master in preparing a portrait of a saint can use a real person as a model (which is strictly forbidden and regarded as a blasphemous action in Orthodox teachings) (DąB-KaLINowsKa 1993: 103). ${ }^{12}$ This is the case with Raphaele Sanzio working on a cycle of images presenting Madonna and using, as it was believed, his mistress Fornarina as a model (cf. STUART 1914: 453). The Western master, however sinful and morally weak, is thought to be able to create a realm of beauty pointing

Holy Scripture - that is, they are not simply artistic compositions but rather are witnesses to the truth the way Scripture is. Far from being imaginative creations of the iconographer, they are more like scribal copies of the Bible. While the explanation of the purpose and nature of icons is certainly true and consistent with the Church's Holy Tradition, there is a linguistic problem with the insistence on the word written rather than painted. In Greek, a painted portrait of anyone is also a $\gamma p a \phi \dot{\eta}$ (graphi), and the art of painting itself is called $\zeta \omega \gamma p \alpha \phi ı \dot{~(z o g r a p h i k e) ~ w h i l e ~ a n y ~ d r a w i n g ~ o r ~ p a i n t i n g ~}$ can be referred to as $\zeta_{\omega} \gamma p \alpha \phi i \dot{\alpha}$ (zographia). Ancient Greek literally uses the same root word to refer to the making of portraits and the making of icons, but distinguishes whether it is "painting from

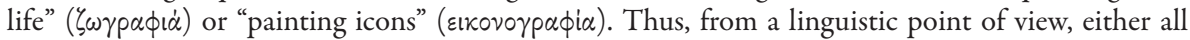
paintings - whether icons or simple portraits - are "written" or (more likely) "painted" is a perfectly usable English translation, simply making a distinction between the painting appropriate for icons and that appropriate for other kinds of painting, just as Greek does." See on the website: EASTERN ORTHODOX AND CATHOLIC TEACHING ABOUT ICONS

10 "Podlinniki" are known in the circle of Russian Orthodoxy, whereas in the circle of Byzantine Church the analogous set of composition patterns and principles of presentation was called "hermeneia." Cf. SMORĄG-RóżYCKA 2003: VIII-IX.

11 Cf. Expectations towards icon authors was clearly voiced in the final document of the Russian Orthodox Council of 1551 (called a "Council of One Hundred Chapters"). Cf. Florenski 1984: 142-147. See also: Jazyкоwa 1998: 20; АрХиманарит РАФАЙ.

12 As the author points out, a real person as a model for an iconographer would have meant a total breaking off from the connection of the archetypal sanctified image. 
out the divine reality. The work of Western artist is regarded to be "neither devotional nor godless" (Cf. БЕзАнСОН 1999: 166).

The Eastern master in turn, convinced that patterns of real beauty are to be found only in the other world, tries to avoid the interspersing of elusive and real elements. That is the reason for imparting a non-mimetic, symbolical form to every detail, colours and patterns of composition. One of the most striking features of icon composition is the principle of diverted perspective creating the impression that all lines are focused in front of the icon on the onlooker looking out from the icon window at a transformed, sanctified reality (cf. EvDOKImov 1999: 189).

Though the images of man are simplified, they pass on two kinds of information: a) symbolic vision of a deified, transfigured person existing in eternity b) metonymic, vestigial items of information about the bodily and social characteristics of the presented person in his or her earthly life (height, sex, occupation).

Icon representations of man can be regarded as a set of symbols: the body itself, even every part of it, gestures, clothes, objects held, applied colours and the perspective presented in a visibly non-mimetic manner bear the symbolical notion of a higher reality. The saints appearing on icons are presented with big, open, piercing eyes, contemplating an extraterrestrial reality invisible for the sinner. Sometimes ascetics were presented with closed eyes, which means that by means of inner glance they look at the image of God imprinted in their soul. The foreheads of the saints are usually very high, meaning that God's wisdom fills them. The very thin, almost marked out with a single line lips of the saints are regarded as the badges of a sinless state. Clenched lips are the indication that the person represented in the picture keeps silence and observes fasts, that he does not violate the commandments through gluttony or bad language. Elongated ears are the indication of a susceptibility to God's voice (cf. EvdoKimov 1996: 131; see also: JazYKowA 1998: 27-28).

The icon though represents a new, transformed man in which his altered body is no longer a prison for his soul, but becomes a sort of temple for it (cf. EvDOKIMOv 1999: 190). A holy person is always presented en face, motionless, with a gaze full of tranquillity. In the case of human beings presented in a profile or caught in motion, with bodies twisted and full of anxiety - the applied devices of composition pass on a message of imperfection, a lack of sanctity (cf. EvDOKImOv 1996: 131)..$^{13}$ Man in that form of existence has not yet reached the state of being - he still remains in the realm of becoming. Therefore, the image of man in an Orthodox icon is constructed by means of a system of symbols and, consequently, the presented person resembles a compound symbol itself. The sign becomes the principle for iconic representation. Image in that case acts as a word. That is the semantic aspect of the statement stressing that man is an icon of God.

Western religious paintings usually used to obey other principles. The Western painter, endowed with artistic licence, creates images that illustrate the truth expressed in the holy text of the scriptures, sermons or hagiography. But pictorial principles, influenced by changing artistic styles, philosophical schools, concepts of man and pat-

13 That principle of presentation is especially visible in icons undertaking the themes of the Transfiguration and Christ's Descend to Hell. See: Evdokimov 1999: 252. 
terns of culture are regarded as the main code of translation from the reality described in words into an actuality expressed by images. In that case the word inspires the artistic imagination and creativity. The form of such an expression is closer to the changing sensitivity of man in consecutive centuries. Western religious art speaks to the believer in a language emerging from culture, whereas Orthodox icon does not change its language, attempting to influence the changing culture. The source of the message being passed on is the same in both cases.

The symbolic, meaningful clarity of Russian Orthodox icons based on observing rigorous canons started to disappear gradually at the beginning of the $19^{\text {th }}$ century (JAZYKOWA 1998: 31) due to the visible influences of Western aesthetic principles. Since that time Russian icons have become more and more imbued with details, decorative motives and mimetic concentration on imitating the profane reality. Icon masters have started to apply techniques of visual illusion, introduce real landscapes and use real persons as models. Disobeying canons led to a replacement of icons by paintings in the religious life of Russia (cf. DĄB-KaLINOwsKa 1990: 126). As a result, "the unity of word and image," regarded since the Council in Nicaea as equal in means for the passing on of Christian teaching, was broken (DĄB-KaLINOwsKa 1990: 126). That process stopped only at the beginning of the $20^{\text {th }}$ century, due to the discovery of the beauty of early Russian icons, which encouraged the Russian Church to redefine their attitude towards icons and return to the forgotten canons of before (ТРУБЕцкой ).

An interesting case in the establishment of intercultural space and recognition of the same values between Roman Catholic and Orthodox believers is the cult of the Black Madonna icon from the monastery in Częstochowa. For Polish Catholics the picture is one of the most revered and worshipped religious paintings. In the Polish Church calendar, a special day for the worship of the Black Madonna falls on $26^{\text {th }}$ of September. For Orthodox believers the image of the Black Madonna is regarded as a holy icon. The Orthodox calendar has designated the $19^{\text {th }}$ of March as a special occasion for the worship of the image. Both Christian Churches used to evoke a legend in connection with the image stating that the Częstochowa Madonna is one of the 70 icons written about by St Luke, who was seen as a person unifying two skills in his service to Christ. As one of the Evangelists and the author of icons as well (cf. CormaCK 1999: 50-52), St Luke used to prove the equality of word and image as appropriate media passing on the same meaning of vital importance.

\section{REFERENCES}

BuŁgakow, Sergiusz 2002: Ikona i kult ikony. Zarys dogmatyczny. Transl. by Henryk Paprocki. Bydgoszcz: "Homini." [Икона и иконопочитание. Аогматитеский очерк].

Chydenius, Johan 1960: The Theory of Medieval Symbolism. (Commentationes Humanarum Litterarum. 27.2.) Helsigfors: Societas Scientiarum Fennica.

Cognar, Yves 1968: "Człowiek i przebóstwienie w teologii prawosławnej," Znak 169-170: 841-865. 
Cormack, Robin 1999: Malowanie duszy. Ikony, maski pośmiertne i catuny. Kraków: Universitas. [Painting the Soul. Icons, Death Mask and Shrouds].

EASTERN ORTHODOX AND CATHOLIC TEACHING ABOUT ICONS. Available under <http:// www.ikonograph.com/teaching-about-icons/> (accessed on December 15, 2016).

DĄв-KalinowsKa, Barbara 1990: Między Bizancjum a Zachodem. Ikony rosyjskie XVII-XIX wieku. Warszawa: PWN.

DąB-KaLINowsKa, Barbara 1993: “Pojęcie ikony i obrazu sakralnego," Znak 2: 94-103.

Evdokimov, Paul 1986: Prawostawie. Transl. by Jerzy Klinger. Warszawa: PAX. [L'Orthodoxie].

Evdokimov, Paul 1996: Poznanie Boga w tradycji wschodniej. Patrystyka, liturgia, ikonografia.

Transl. by Alina Liduchowska. Kraków: Wydawnictwo M. [La connaissance de Dieu selon la tradition orientale].

Evdokimov, Paul 1999: Sztuka ikony. Teologia piękna. (Bogosłowije. 2.) Transl. by Maria Żurowska. Warszawa: Wydawnictwo Księży Marianów. [L’art de l'icône. Théologie de la beauté].

Florenski, Paweł 1984: Ikonostas, in: Idem: Ikonostas i inne szkice. Transl. by Zbigniew Podgórzec. Warszawa: PAX, pp. 142-147. [Нконостас].

GadAmer, Hans-Georg 1991: Symbol i alegoria, in: Michał Głowiński (ed.): Symbole i symbolika. (Panorama.) Warszawa: Czytelnik. [Umanesimo e simbolismo].

Gatrall, Jeff 2001: "Between Iconoclasm and Silence: Representing the Divine in Holbein and Dostoevskii," Comparative Literature 53(3): 214-232. DOI: 10.2307/3593496.

Gilson, Étienne 1953: Wprowadzenie do nauki świętego Augustyna. Transl. by Zygmunt Jakimiak. Warszawa: PAX. [Introduction à l'étude de Saint-Augustin].

HrYNiEWICZ, Wacław 1972: “Współczesna antropologia prawosławna," Analecta Cracoviensia 4: $217-238$.

St Irenaeus of Lyon: Adversus haereses, V, preface. I quote after: Vladimir Lossky, 1985: In the Image and Likeness of God. Crestwood, N.Y.: St Vladimir's Seminary Press.

Jakobson, Roman 1971: "Language in Relation to other Communication Systems," in: Idem: Selected Writings. Vol. 2. Word and Language, The Hague/Paris: Mouton.

Jazykowa, Irina 1998: Świat ikony. (Bogosłowije. 1.) Transl. by Henryk Paprocki. Warszawa: Wydawnictwo Księży Marianów. [Богословие иконы]].

Leclerce, Henri 1911: The First Council of Nicaea, in: The Catholic Encyclopedia. Vol. 11. New York: Robert Appleton Company. Available under <http://www.newadvent.org/ cathen/11044a.htm> (accessed on August 28, 2013).

Lossky, Vladimir 1985: In the Image and Likeness of God. Crestwood, N.Y.: St Vladimir's Seminary Press.

Łukaszuk, Tadeusz Dionizy 1998: “Obraz święty - ikona w kulcie Maryi na Wschodzie i na Zachodzie," in: Julian Wojtkowski, Stanisław Celestyn Napiórkowski (eds.): Nosicielka Ducha. Pneumatofora. Materiaty Kongresu Mariologicznego, Jasna Góra 18-23 sierpnia 1996 r. Lublin: Redakcja Wydawnictw KUL.

Meyendorff, John 1984: Teologia bizantyjska. Historia i doktryna. Transl. by Jerzy Prokopiuk. Warszawa: PAX. [Byzantine Theology. Historical Trends and Doctrinal Themes].

Mortal immortal: Mortal immortal: Christopher S. Wood on Hans Holbein the Younger. Available under <http://www.thefreelibrary.com/Mortal+immortal\%3A+Christopher+S. +Wood+on+Hans+Holbein+the+Younger.-a0141095861> (accesed on August 29, 2013). 
PAProcki, Henryk 2011: "Związki pomiędzy ikoną, teologią i liturgią, Elpis. Czasopismo teologiczne Katedry Teologii Prawostawnej Uniwersytetu w Biatymstoku 23-24: 39-58.

Shahan, Thomas 1908: Caroline Books (Libri Carolini), in: The Catholic Encyclopedia. Vol. 3. New York: Robert Appleton Company. Available under < http://www.newadvent. org/cathen/03371b.htm> (accessed on August 29, 2013).

SMORĄG-RóżyCKA, Małgorzata 2003: Wstęp, in: Dionizjusz z Furny: Hermeneia czyli objaśnienie sztuki malarskiej. Transl. by Ireneusz Kania. Kraków: Wydawnictwo Uniwersytetu Jagiellońskiego, pp. VIII-IX.

ŠPIDlík, Thomas 2005: Duchowość chrześcijańskiego Wschodu. Przewodnik systematyczny. Transl. by Lucyna Rodziewicz. Kraków: Wydawnictwo OO. Franciszkanów "Bratni Zew." [La spiritualité de l'Orient chrétien. Manuel systematique].

StUart, Evelyn Marie 1914: "Great Artists and Their Love Affairs: Raphael and Margarita (Chapter I)," Fine Arts Journal 31(3): 445-454. DOI: 10.2307/25587274.

USPIENSKI, Boris 1975: O systemie przekazu obrazu w rosyjskim malarstwie ikon, in: Elżbieta Janus, Maria Renata Mayenowa (eds.): Semiotyka kultury. (Biblioteka Myśli Współczesnej.) Warszawa: PIW. [К системе передачи изображения в русской иконописи].

WOLICKA-WOLSZleger, Elżbieta 2010: O różnych typach wyobraźni symbolicznej, in: Eadem: Obrazy sa korzeniami myśli. (Sztuka Nowa. 7.) Lublin: Towarzystwo Naukowe KUL.

АрХиманарит РАФАИл (Карелин): О язбке православной иконы, Москва 1997. Pdf version available under <http://karelin-r.ru/nuke/books/11.pdf> (accesed on December 10, 2016).

БезАнсон, Ален 1999: Запретньй образ. Интеллетуальная история иконоборчества. Москва: Издательство МИК 1999. [Alain Besançon, L'image interdite: une histoire intellectuelle de l'iconoclasme].

АуАЕк, Анажей 2010: “На пути к 'внутреннему человеку." Концепция самопознания в творчестве Вячеслава Иванова," in: К. Ю. Ааппо-Аанимевский, А. Б. Шишкин (eds.): Вячеслав Иванов. Исследования и материаль. Вып. 1. Санкт-Петербург: Издательство Пушкинского Аома 2010, pp. 53-64.

Труьецкой, Евгений: Умозрение в красках. Этюды по русской иконописи. Available under <https://azbyka.ru/otechnik/Evgenij_Trubeckoj/umozrenie-v-kraskah/3_4> (accessed on December 15, 2016).

Andrzej DUDEK, Ph.D., Associate Professor, Head of the Section of Anthropology of Russian Culture at the Institute of Russian and East European Studies. Research interests: culture, literature and religious thought in Russia, the Russian mentality, the Russian émigré culture, Western and Russian concepts of culture. Author of monographs: Modele romantyzmu i realizmu $w$ liryce rosyjskiej lat czterdziestych XIX $w$., Kraków 1992; Wizja kultury w twórczości Wiaczestawa Iwanowa, Kraków: Wyd. UJ 2000. His research articles and chapters published in the Czech Republic, Great Britain, Italy, Netherlands, Russia and Poland are devoted mainly to the culture of Russian modernism. Member of The Committee of Slavic Studies of the Polish Academy of Sciences. 